\title{
Leaf Size and Leaf Area Index in Fagus sylvatica Forests: Competing Effects of Precipitation, Temperature, and Nitrogen Availability
}

\author{
Ina C. Meier and Christoph Leuschner*
}

Plant Ecology, Albrecht-von-Haller-Institute for Plant Sciences, University of Göttingen, Untere Karspüle 2, 37073 Göttingen, Germany

\begin{abstract}
Plants across diverse biomes tend to produce smaller leaves and a reduced total leaf area when exposed to drought. For mature trees of a single species, however, the leaf area-water supply relationship is not well understood. We tested the paradigm of leaf area reduction upon drought by a transect study with 14 mature Fagus sylvatica forests along a steep precipitation gradient $\left(970-520 \mathrm{~mm} \mathrm{y}^{-1}\right)$ by applying two independent methods of leaf size determination. Contrary to expectation, average leaf size in dry stands $\left(520-550 \mathrm{~mm} \mathrm{y}^{-1}\right)$ was about $40 \%$ larger and SLA was higher than in moist stands $\left(910-970 \mathrm{~mm} \mathrm{y}^{-1}\right)$. As a result of increased leaf sizes, leaf area index significantly increased from the high- to the low-precipitation stands. Multiple regression analyses suggested that average leaf size was primarily controlled by temperature, whereas the influence of soil moisture and soil $C / N$ ratio was low. Summer rainfall of the preceding year was the
\end{abstract}

\section{INTRODUCTION}

There is a vital debate on how temperate trees may respond to an increased frequency and severity of summer droughts as is predicted in recent climate change scenarios for parts of Central Europe (IPCC 2001, 2007; Rowell and Jones 2006). This question

Received 4 September 2007; accepted 28 January 2008; published online 31 May 2008

*Corresponding author; e-mail: cleusch@uni-goettingen.de most significant predictor of total leaf number. We assume that leaf expansion of beech was independent of water supply, because it takes place in May with ample soil water reserves along the entire transect. In contrast, bud formation, which determines total leaf number, occurs in mid-summer, when droughts are severest. We conclude that leaf expansion and stand leaf area of beech along this precipitation gradient are not a simple function of water availability, but are controlled by several abiotic factors including spring temperature and possibly also nitrogen supply, which both tend to increase toward drier sites, thus overlaying any negative effect of water shortage on leaf development.

Key words: adult trees; bud formation; drought; European beech; LAI; leaf expansion; leaf population; precipitation gradient. is particularly relevant for economically important tree species such as European beech (Fagus sylvatica L.). This species has a sub-oceanic distribution and exhibits a number of physiological and morphological traits that characterize it as comparatively drought-sensitive (Backes and Leuschner 2000; Granier and others 2007) even though the morphological and physiological drought response of beech may differ among genotypes (Peuke and others 2002). Therefore, reduced summer rainfall 
could threaten beech forests in regions of Central Europe, where this species is actually growing near its drought limit.

Numerous laboratory experiments with herbaceous plants and tree seedlings or saplings have shown that leaf area reduction is a common response to soil water shortage (for example, Fischer and Turner 1978; Begg 1980; Poorter 1989; Lof and Welander 2000; Pedrol and others 2000; Otieno and others 2005), thereby reducing the transpiring surface area and avoiding severe decreases in cell water potential and turgor (Hinckley and others 1981; Kozlowski and Pallardy 1997). Tree leaf area and stand leaf area index (LAI, the one-sided cumulative surface area of all leaves per unit ground area) are of paramount importance for forest biogeochemical fluxes because radiation interception, productivity, canopy conductance, and stand transpiration are all closely linked to LAI (Gholz and others 1990; Bréda and Granier 1996; Kozlowski and Pallardy 1997; Welander and Ottoson 1997).

If the response of trees and forests to a possibly drier climate is to be predicted, long-term adaptive responses and highly flexible resource allocation patterns in these long-lived plants must be taken into account. This makes simple extrapolation from laboratory seedling or sapling studies to mature forests difficult if not impossible. Much more realistic results can be expected from large manipulation experiments in the field such as throughfall displacement experiments, where a reduced precipitation is simulated (for example, Wullschleger and Hanson 2006). However, due to high costs and restrictions in personnel, most large-scale water manipulation experiments in forests suffer from missing replication and short duration with the consequence that adaptive responses of trees are only rarely covered. Another source of information can be comparative studies in forest stands along precipitation gradients which may provide valuable additional information for understanding longterm tree adaptation to drought if the sites are carefully selected and other environmental factors are kept sufficiently constant.

Studies on LAI and leaf morphology changes in mature forest stands of a single tree species along precipitation or soil moisture gradients have only rarely been conducted so far. The existing gradient studies in forests focusing on the leaf area-water supply relationship referred to long gradients and typically included a tree species replacement between the moist and dry ends of the gradient (for example, Grier and Running 1977; Hinckley and others 1981; Runyon and others 1994; Turner
1994; Jose and Gillespie 1997; Cunningham and others 1999; Reich and others 1999; Wright and others 2004). This kind of data may allow general conclusions on how water shortage affects forest leaf area within biomes, but it gives no insight into a tree species' adaptive potential with respect to leaf area development and leaf morphology.

European beech forms mono-specific stands under a broad range of soil chemical and hydrological conditions, from highly acidic to basic soils (Leuschner and others 2006a), and from low to high rainfall regimes. Hence, this species provides unique opportunities for investigating a tree species' response to water availability in the field by covering a broad range of soil moisture or rainfall conditions. In this study, we compared the leaf area development of 14 mature beech forests of similar age and structure along a steep precipitation gradient (520-970 $\mathrm{mm} \mathrm{y}^{-1}$ ), while other environmental factors were by far less variable. Study aims were to test the paradigm of a decrease in LAI and mean leaf size with declining rainfall for mature trees of a single species, thereby improving our understanding of long-term adaptive drought responses of temperate trees.

\section{Materials And Methods}

\section{Study Area and Forest Stands}

The study was conducted in the center of the distribution area of Fagus sylvatica in southern Lower Saxony, northern Thuringia, and southwestern Saxony Anhalt in central Germany. Fourteen mature beech forests with comparable stand structure were selected for study (Table 1). The sites were chosen along a 150-km-long WNW-ESE transect in level to slightly sloping terrain at elevations of 230 $440 \mathrm{~m}$ a.s.l. All stands grew on the same geological substrate (Triassic sandstone of Middle Bunter) to enhance comparability of soil chemical conditions. Mean annual temperature was $7.8^{\circ} \mathrm{C}$ along the transect, with a tendency for slightly higher temperatures in the eastern, more continental section of the transect. Mean annual precipitation decreased from the west $\left(970 \mathrm{~mm} \mathrm{y}^{-1}\right)$ to the east $\left(520 \mathrm{~mm} \mathrm{y}^{-1}\right)$, reflecting the transition from a suboceanic to a more sub-continental climate in the rain shadow of the Solling and Harz mountains. The corresponding summer rainfall (May-September) decreased from 420 to $270 \mathrm{~mm} \mathrm{y}^{-1}$. As in other rainfall transects, temperature and nutrient supply changed along the transect as well. However, the variability of temperature, $\mathrm{pH}$, and $\mathrm{C} / \mathrm{N}$ ratio was much smaller than that of precipitation 


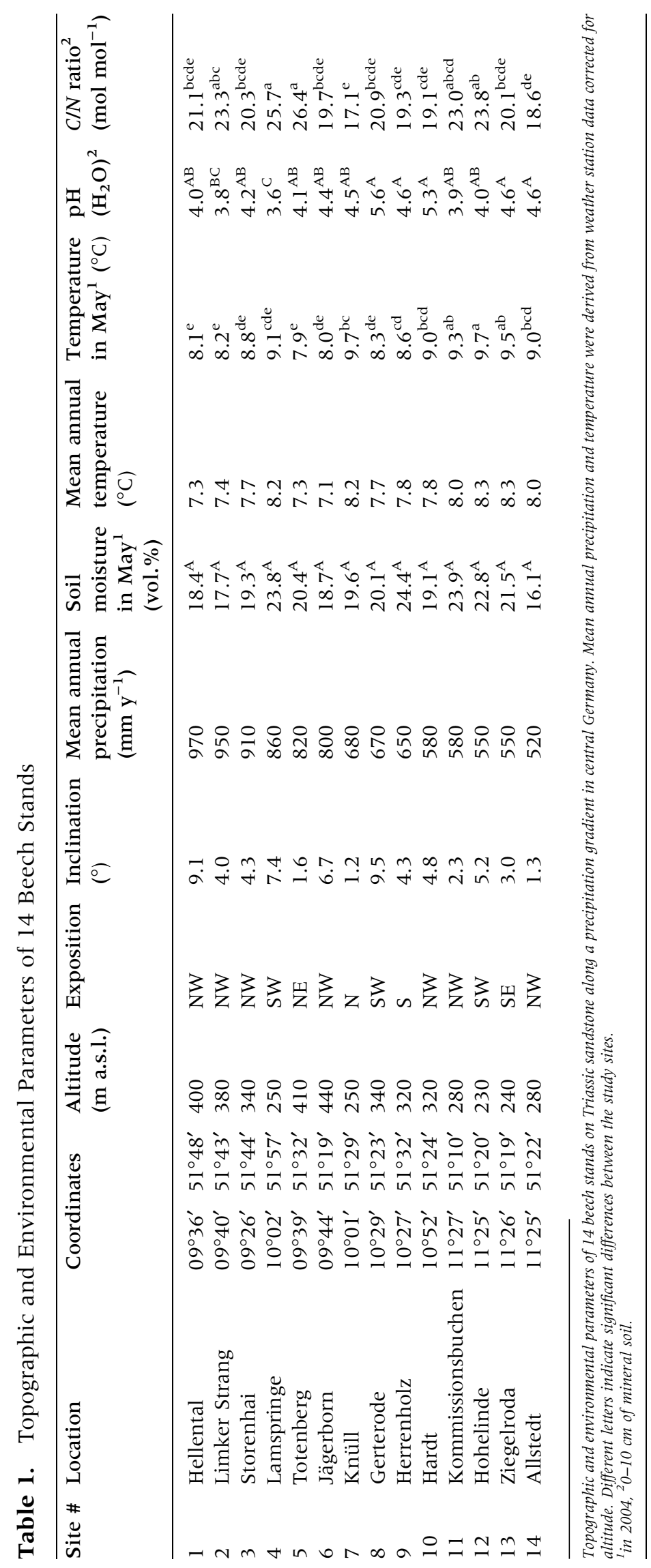


Table 2. Stand Structural and Leaf Characteristics of the 14 Beech Forests

\begin{tabular}{|c|c|c|c|c|c|c|c|c|c|c|c|}
\hline \multirow[t]{3}{*}{ Site \# } & \multirow{3}{*}{$\begin{array}{l}\text { Stand } \\
\text { age (a) }\end{array}$} & \multirow{3}{*}{$\begin{array}{l}\text { Stem } \\
\text { density } \\
\left(\mathrm{n} \mathrm{ha}^{-1}\right) \\
\text { Mean }\end{array}$} & \multirow{2}{*}{\multicolumn{2}{|c|}{$\begin{array}{l}\text { Tree } \\
\text { height }(\mathrm{m})\end{array}$}} & \multirow{2}{*}{\multicolumn{2}{|c|}{ BHD $(\mathrm{cm})$}} & \multirow{3}{*}{$\begin{array}{l}\text { Cumulative } \\
\text { basal area } \\
\left(\mathrm{m}^{2} \mathrm{ha}^{-1}\right) \\
\text { Mean }\end{array}$} & \multicolumn{4}{|c|}{ Specific leaf area $\left(\mathrm{m}^{2} \mathrm{~kg}^{-1}\right)$} \\
\hline & & & & & & & & \multicolumn{2}{|l|}{2003} & \multicolumn{2}{|l|}{2004} \\
\hline & & & Mean & S.E. & Mean & S.E. & & Mean & S.E. & Mean & S.E. \\
\hline 1 & 136 & 189 & $32.9^{\mathrm{AB}}$ & 0.9 & $36.1^{\mathrm{a}}$ & 3.1 & 30.3 & ${ }^{\alpha} 20.6^{\mathrm{ABC}}$ & 0.2 & ${ }^{\beta} 18.3^{\text {cde }}$ & 0.3 \\
\hline 2 & 153 & 189 & $33.7^{\mathrm{AB}}$ & 0.7 & $46.0^{\mathrm{a}}$ & 3.9 & 35.0 & ${ }^{\alpha} 17.4^{\mathrm{B}}$ & 0.2 & ${ }^{\beta} 15.8^{\mathrm{e}}$ & 0.3 \\
\hline 3 & 126 & 178 & $37.1^{\mathrm{A}}$ & 1.5 & $47.1^{\mathrm{a}}$ & 2.7 & 32.5 & ${ }^{\alpha} 20.1^{\mathrm{BC}}$ & 0.2 & $\beta 19.0^{\text {bcde }}$ & 0.3 \\
\hline 4 & 99 & 189 & $31.6^{\mathrm{AB}}$ & 0.5 & $40.5^{\mathrm{a}}$ & 3.4 & 30.6 & $20.9^{\mathrm{ABC}}$ & 0.2 & $20.3^{\mathrm{abcd}}$ & 0.8 \\
\hline 5 & 157 & 178 & $32.4^{\mathrm{AB}}$ & 0.8 & $39.0^{\mathrm{a}}$ & 4.0 & 31.8 & ${ }^{\alpha} 20.7^{\mathrm{ABC}}$ & 0.6 & ${ }^{\beta} 17.4^{\mathrm{de}}$ & 0.5 \\
\hline 6 & 143 & 144 & $33.3^{\mathrm{AB}}$ & 0.2 & $46.2^{\mathrm{a}}$ & 3.8 & 30.5 & ${ }^{\alpha} 21.7^{\mathrm{AB}}$ & 0.4 & ${ }^{\beta} 18.6^{\mathrm{cde}}$ & 0.2 \\
\hline 7 & 90 & 200 & $33.1^{\mathrm{AB}}$ & 0.4 & $35.5^{\mathrm{a}}$ & 2.3 & 21.3 & ${ }^{\alpha} 20.8^{\mathrm{ABC}}$ & 0.5 & ${ }^{\alpha} 20.7^{\mathrm{abcd}}$ & 0.6 \\
\hline 8 & 132 & 256 & $32.6^{\mathrm{AB}}$ & 1.4 & $31.8^{\mathrm{a}}$ & 2.4 & 27.4 & ${ }^{\alpha} 24.0^{\mathrm{A}}$ & 0.5 & $\alpha 22.3^{\mathrm{abc}}$ & 0.9 \\
\hline 9 & 98 & 200 & $35.0^{\mathrm{AB}}$ & 0.4 & $33.5^{\mathrm{a}}$ & 3.8 & 27.3 & ${ }^{\alpha} 21.5^{\mathrm{AB}}$ & 0.6 & ${ }^{\alpha} 19.8^{\mathrm{abcd}}$ & 0.6 \\
\hline 10 & 139 & 189 & $37.8^{\mathrm{A}}$ & 1.6 & $47.9^{\mathrm{a}}$ & 2.5 & 37.7 & ${ }^{\alpha} 22.2^{\mathrm{AB}}$ & 0.5 & ${ }^{\alpha} 23.1^{\mathrm{ac}}$ & 0.6 \\
\hline 11 & 99 & 289 & $34.0^{\mathrm{AB}}$ & 1.0 & $38.4^{\mathrm{a}}$ & 2.4 & 36.8 & ${ }^{\alpha} 22.2^{\mathrm{AB}}$ & 0.9 & ${ }^{\beta} 19.8^{\mathrm{acd}}$ & 0.6 \\
\hline 12 & 131 & 200 & $29.6^{\mathrm{B}}$ & 1.3 & $45.1^{\mathrm{a}}$ & 2.2 & 33.1 & ${ }^{\beta} 21.4^{\mathrm{AB}}$ & 0.5 & ${ }^{\alpha} 23.0^{\mathrm{ac}}$ & 0.5 \\
\hline 13 & 132 & 167 & $35.8^{\mathrm{AB}}$ & 0.9 & $51.3^{\mathrm{a}}$ & 3.5 & 39.4 & $22.4^{\mathrm{AB}}$ & 0.6 & n.i. & \\
\hline 14 & 123 & 344 & $32.7^{\mathrm{AB}}$ & 0.5 & $33.7^{\mathrm{a}}$ & 2.4 & 48.8 & ${ }^{\alpha} 23.7^{\mathrm{AB}}$ & 0.9 & ${ }^{\beta} 21.2^{c}$ & 0.6 \\
\hline
\end{tabular}

Stand structural characteristics and specific leaf area (SLA) of the 14 beech forests on Triassic sandstone in 2003 and 2004 along a precipitation gradient in central Germany. Stem density refers to all canopy layer trees; tree height: mean and standard error of eight trees per site, breast height diameter (BHD): mean and standard error of all trees with greater than 10-cm stem diameter per site, cumulative basal area: sum of the basal area of all trees per site. Each 50 leaves were randomly collected in leaf buckets immediately after leaf fall; values given are mean and standard error of $n=10$ buckets per site; total number of leaves analyzed per site $=500$. Different Greek letters indicate significant differences between the study years and different Latin letters mark significant differences between the sites during a given study year. n.i. = not investigated.

(see Table 1), which nearly doubled from the East to the West. For simplicity, we talk of a precipitation gradient hereafter.

Selection criteria for the stands were (i) closed canopy without major gaps, (ii) even-aged stand structure (100-140 years old; extremes 90157 years), (iii) no significant presence of other tree species, and (iv) 175-250 stems per hectare. The stands were founded either from seeds or from planting of seedlings of autochthonous (local) origin. In European beech, genetic variation among different stands has been found to be low (Comps and others 1990) which reduced a possible genetic influence on leaf area development along the studied gradient. Typically, beech formed a single closed canopy (mono-layer) with a second tree layer and shrubs being mostly absent. Forest management activities in the stands had not been conducted for at least 7 years, in most cases for more than 10 years prior to the study. Most of the stands fit this scheme. However, a higher total stem density existed in stand \#14, where 233 stems ha $^{-1}$ reached the upper canopy and 111 thinner beech trees formed a sparse second layer. Mean tree height in the upper canopy layer was $34 \mathrm{~m}$ in the 14 stands (extremes: 30-38 m), mean breast height diameter was $41 \mathrm{~cm}$ $(32-51 \mathrm{~cm}$; Table 2$)$. The sites were not affected by compensatory liming activities of forestry except for stand \#6 (8 years ago) and \#3 (13 years ago).
We were not able to monitor soil moisture continuously at the 14 sites; however, TDR measurements of soil moisture were conducted every second month at $0-20-\mathrm{cm}$ soil depth in all stands. In addition, one beech stand each at the moist and dry ends of the transect was equipped with continuously logging TDR- and tensiometer stations in 2003 (15-20-cm depth; data for the moist site according to Meesenburg (unpubl.)). According to the occasional and continuous soil moisture measurements, the lower rainfall at the dry end corresponds to lower absolute soil moisture minima and a longer duration of low soil water contents in summer in comparison to the sites at the moist end of the transect (Figure 1A and B). The nitrogen content and the $\mathrm{C} / \mathrm{N}$ ratio of the mineral topsoil $(0$ $10 \mathrm{~cm}$ ) were analyzed in five samples per stand.

We used two independent approaches to determine leaf size in the canopy of the stands (a) by analyzing fresh fallen leaves collected in autumn in litter buckets, and (b) by investigating leaves harvested with a crossbow in the upper sun canopy in mid-summer.

The leaf area measurements with leaf litter took place in 2003 and 2004, two years with a highly contrasting precipitation and temperature regime. The summer 2003 was the hottest summer in the region since 1901 with a $20 \%$ lower annual precipitation than the long-term average in the study 

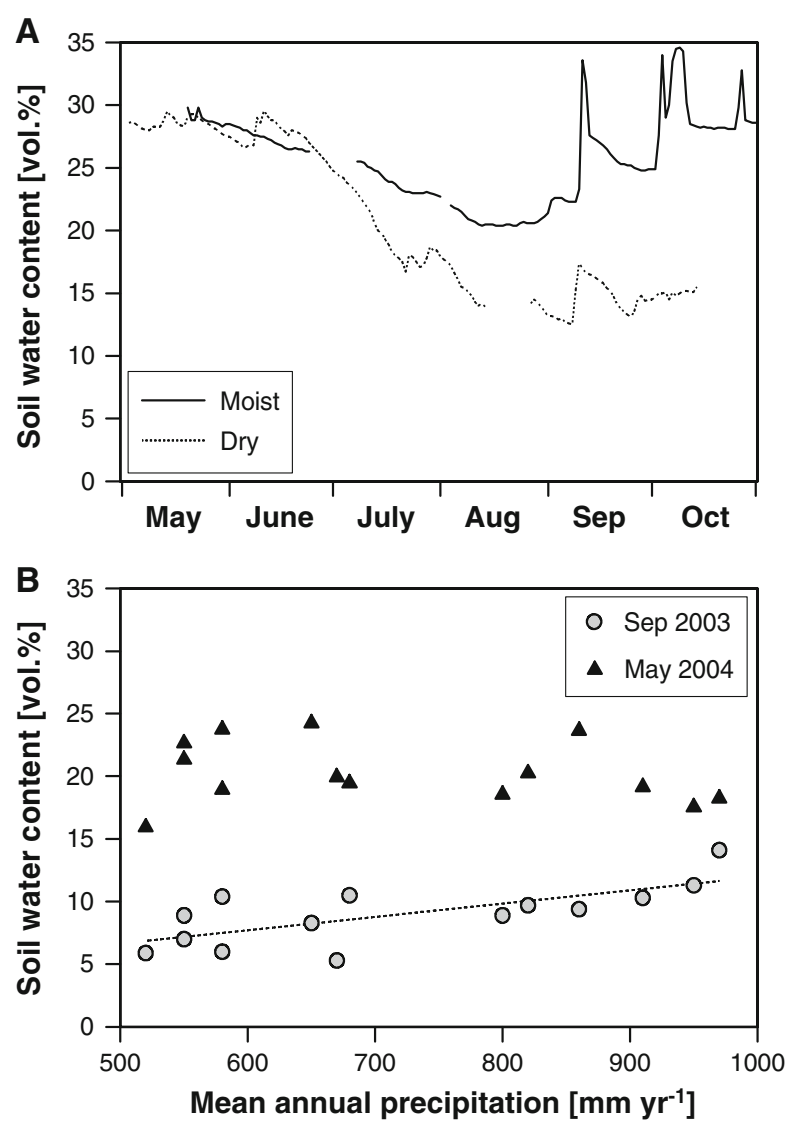

Figure 1. (A) Soil water content $(15-20 \mathrm{~cm})$ in a beech stand on the moist $\left(>950 \mathrm{~mm} \mathrm{y}^{-1}\right)$ and the dry end $\left(<550 \mathrm{~mm} \mathrm{y}^{-1}\right)$ of the investigated precipitation gradient in central Germany. Values given are data for the growing season in the dry year 2003. Data for the moist beech stand according to Meesenburg (unpubl.) and for the dry beech stand according to Burk (2006). (B) Relationship between mean annual precipitation and soil water content $(0-20 \mathrm{~cm})$ in spring and late summer in 14 beech stands along the precipitation gradient in central Germany (mean of 10 sampling points per study site). Values given are data for September 2003 at the end of a dry summer and May 2004 at the time of leaf flush (Sep 2003: $y=1.3+0.01 x, r^{2}=0.50, P=0.002$; May 2004: $\left.r^{2}=0.06, P=0.21\right)$.

area. In contrast, the summer 2004 was $20 \%$ wetter than the average record for the study area.

\section{Determination of Leaf Area, Leaf Mass, and Leaf Morphology}

Stand leaf mass $\left(M_{1}\right.$, which equals annual leaf production) and LAI were recorded by litter trapping in 2003 and 2004 in all the 14 stands. Ten litter buckets (aperture: $0.28 \mathrm{~m}^{2}$ ) per stand were installed in rectangular plots of $4 \mathrm{~m} \times 20 \mathrm{~m}$ with the buckets being positioned systematically in a grid with 4-m mesh width. The buckets had a perforated bottom and stood $10 \mathrm{~cm}$ above the forest floor with the opening being at $40-\mathrm{cm}$ height. The placing of the rectangular $4 \mathrm{~m} \times 20 \mathrm{~m}$ sampling plots in the stands followed the stand homogeneity criteria defined above; the exact position was defined by a random procedure. All 140 litter buckets were emptied once immediately after the autumnal litter fall. Because this sampling design could introduce a certain error in leaf mass determination, we conducted an error calculation. We estimated that, at the most, $10 \%$ of total canopy leaf mass was subject to pre-senescent leaf litter fall in August or September. This leaf mass remained in the buckets for 6-10 weeks and may have started to decompose. According to Albers and others (2004) and Heim and Frey (2004), 6-12\% of leaf mass is lost in these first weeks of decomposition in beech leaves. Thus a maximum error of $1.2 \%$ in leaf mass calculation can be expected due to this type of error. With regard to mass loss, differences between moist and dry sites should be small, because litter quality typically is a better predictor of litter decomposition than climate at the beginning of the decomposition process (Aerts 1997; Berg and others 2000; Heim and Frey 2004).

The leaf samples were stored at $6^{\circ} \mathrm{C}$ and sorted into leaf and non-leaf fractions. Fifty leaves per bucket were randomly selected and analyzed for leaf area using a flat-bed scanner and the computer program Win FOLIA (Régent Instruments, Quebec, Canada). Subsequently, the total leaf mass was dried $\left(70^{\circ} \mathrm{C}, 48 \mathrm{~h}\right)$ and weighed and the specific leaf area (SLA) calculated. LAI was obtained by multiplying $\mathrm{M}_{1}$ with the stand average of SLA.

Leaves of the upper sun canopy were harvested in July/August 2005 and 2006 with a crossbow in 10 (2005: seven) of the 14 stands. Eight (2005: six) branches were collected per stand and a total of 30 (180) randomly selected leaves analyzed for size. All leaves of a branch were mixed and the eight (six) mixed samples were dried $\left(70^{\circ} \mathrm{C}, 48 \mathrm{~h}\right)$ and weighed, and the SLA calculated. The dried samples were ground and the carbon isotope signature of plant dry mass was analyzed by mass spectroscopy (Delta plus, ThermoFinnigan, USA) in the Centre for Stable Isotope Research and Analysis (KOSI) of the University of Göttingen.

\section{Statistical Analyses}

All data were tested for probability of fit to normal distribution by a Shapiro-Wilk test. In case of Gaussian distribution of the data, study site means were compared with a Scheffé test. Weibull func- 
tions were fitted to the size data of the leaf populations of the stands. To identify the most influential gradients related to environmental or stand structural parameters in the 14 stands, we applied a principal components analysis to factors that were found to be related to leaf morphology, but were mostly independent from each other (precipitation, $C / N$, temperature, stem density, stand age). Subsequently, we employed stepwise multiple regression analyses with backward variable elimination to quantify the effect of the putative key influential factors during leaf flush in May or during bud formation in August of the preceding year (climate, soil chemistry, or stand structure). These analyses were accompanied by single-factor linear regression analyses with the key climate, soil chemistry, or stand structure parameters. Significance was determined at $p$ less than 0.05 in all tests.

\section{RESUlts}

Total Number of Leaves, Average Leaf Size, and Leaf Morphology

According to the litter bucket data, the total number of beech leaves per ground area ranged from 2700 to $5000 \mathrm{~m}^{-2}$ in the 14 stands (Figure $2 \mathrm{~B}$ ). Although the number remained constant across the transect in 2004, it decreased by about $15 \%$ from the high- $\left(970 \mathrm{~mm} \mathrm{y}^{-1}\right)$ to the lowprecipitation stands $\left(520 \mathrm{~mm} \mathrm{y}^{-1}\right)$ in 2003. In contrast, average leaf size increased in all years along this transect from the high- to the lowprecipitation stands as evidenced by both the leaf litter data and the sun-canopy leaves harvested in mid-summer (Figures 2A, 3A). Beech trees growing with less than $550 \mathrm{~mm} \mathrm{y}^{-1}$ had, on average, $35-45 \%$ larger leaves than trees with greater than $910 \mathrm{~mm} \mathrm{y}^{-1}$. The larger leaves in the low-precipitation stands had a significantly higher mean SLA than the leaves in the moister stands (Table 2). Thus, the drier the climate, the larger and thinner the leaves were. Leaf size and SLA showed a similar dependence on precipitation in the dry summer 2003 and in the wet summer 2004, even though the absolute values of leaf size and SLA were different between the years. As expected, average leaf size was higher in the litter buckets, which contained the whole leaf population, than in the corresponding sun-canopy samples. The leaf populations in the litter fall samples showed not only an increase in mean values from the moist to the dry end of the gradient, but were also more right-skewed in their distribution with larger leaf size maxima
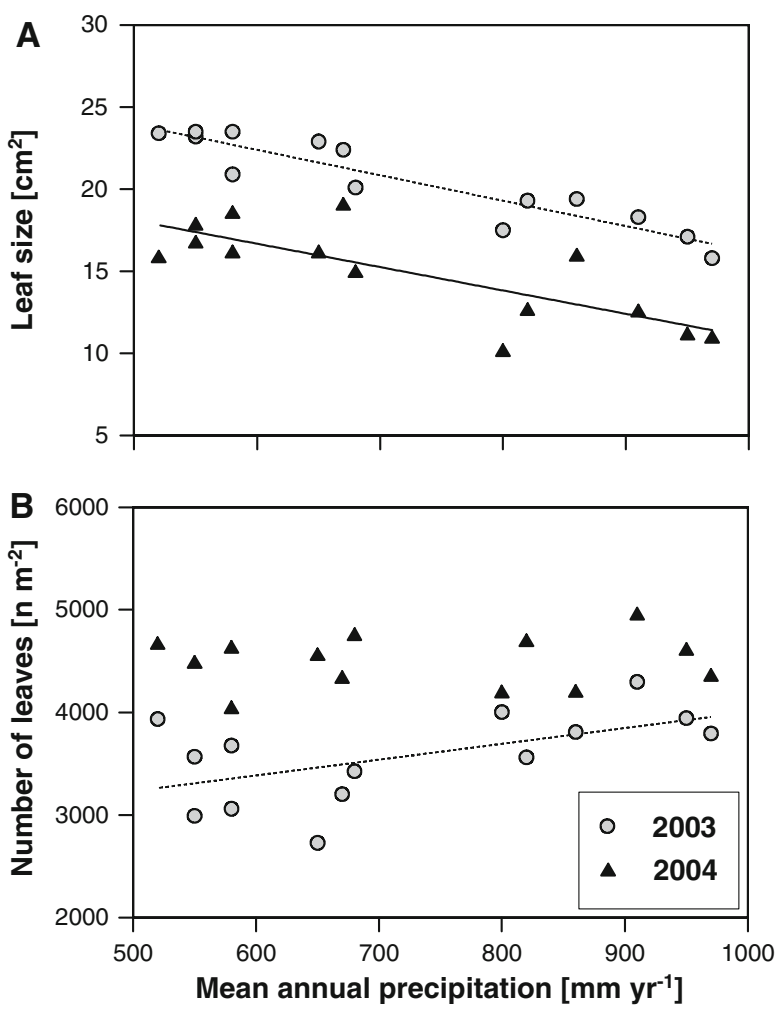

Figure 2. (A, B) Relationship between mean annual precipitation and average leaf size or number of leaves determined at the time of leaf fall in 14 mature beech stands along a precipitation gradient in central Germany (mean of 500 leaves randomly collected from 10 litter buckets per site). Values given are data for the dry year 2003 and the moist year 2004 (leaf size 2003: $y=31.7-0.02 x, \quad r^{2}=0.85, \quad P<0.001 ; \quad 2004$ : $y=25.5-0.01 x, r^{2}=0.61, P=0.001$; number of leaves 2003: $y=2462+1.5 x, \quad r^{2}=0.31, \quad P=0.02 ; \quad 2004$ : $\left.r^{2}=0.01, P=0.40\right)$.

and an overall increase in leaf size variability toward the drier stands (Figure 4). Moreover, the moister stands, but not the drier stands, showed a large increase in maximum leaf size in the dry summer 2003, which resulted in higher leaf sizes in the dry than in the wet year.

\section{Stand Leaf Mass and LAI}

Stand leaf mass $\left(M_{1}\right.$, which is equivalent to annual leaf production) varied between 265 and $393 \mathrm{~g} \mathrm{~m}^{-2}$ in the 14 stands in the two study years (mean 2003: 340, 2004: $339 \mathrm{~g} \mathrm{~m}^{-2}$ ); most values ranged between 320 and $390 \mathrm{~g} \mathrm{~m}^{-2}$ (Figure 5A). In 2003, no significant relationship between $M_{\mathrm{l}}$ and precipitation existed; in contrast, $M_{1}$ increased with decreasing precipitation in 2004. LAI as derived from the litter fall data showed a significant increase from the high- to the low-precipitation 

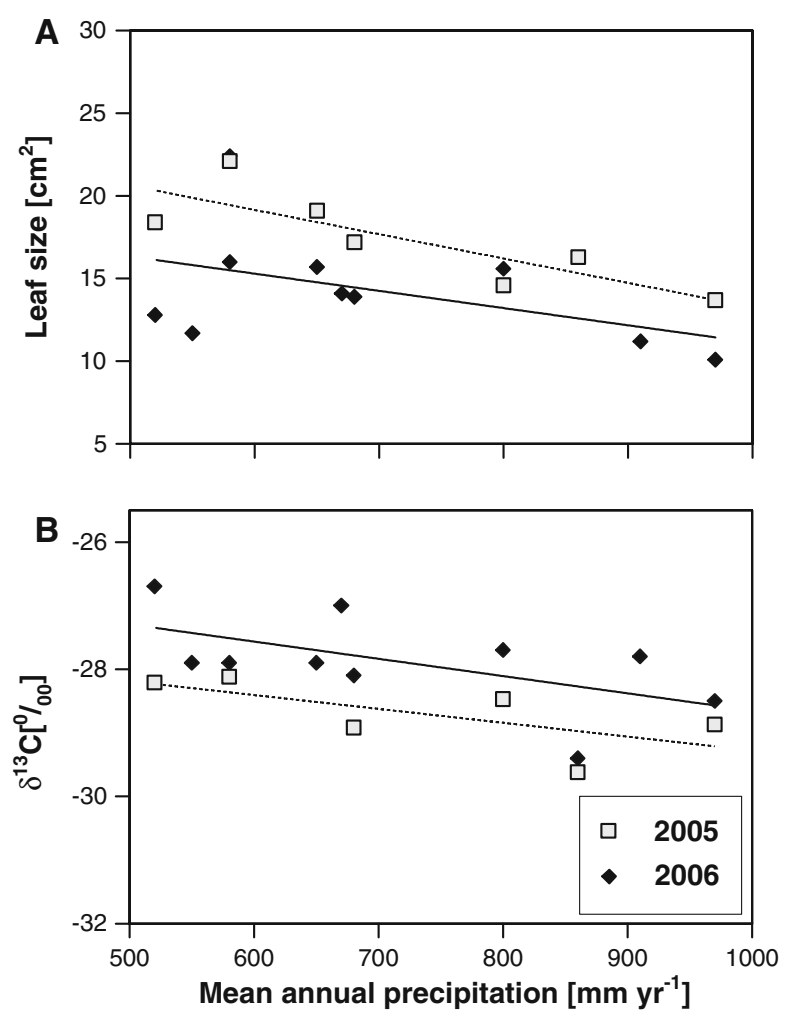

Figure 3. (A, B) Relationship between mean annual precipitation and average leaf size or $\delta^{13} \mathrm{C}$-signature of leaves sampled in mid-summer in the upper sun canopy of 10 (2005: seven) mature beech stands along a precipitation gradient in central Germany (mean of 180 and 30 sun leaves randomly collected with a crossbow from three and two tree individuals per site in 2005 and 2006, respectively; $n=6$ and 8 for $\delta^{13} \mathrm{C}$, respectively). Values given are data for the years 2005 and 2006 (leaf size 2005: $y=28.0-0.01 x, \quad r^{2}=0.68, \quad P=0.01 ; \quad 2006$ : $y=21.5-0.01 x, \quad r^{2}=0.21, \quad P=0.09 ; \quad \delta^{13} \mathrm{C}$-signature 2005: $\quad y=-27.1-0.002 x, \quad r^{2}=0.45, \quad P=0.07 ; \quad 2006$ : $y=25.9-0.003 x, r^{2}=0.33, \quad P=0.04 ;$ data for 2006 according to Fritz, unpubl).

stands in both years (Figure 5). LAI ranged between 6.0 and $9.2 \mathrm{~m}^{2} \mathrm{~m}^{-2}$ in 2003 (mean of the 14 stands: 7.2 ) and between 4.9 and $8.5 \mathrm{~m}^{2} \mathrm{~m}^{-2}$ in 2004 (mean: 6.8). The stands with less than $550 \mathrm{~mm} \mathrm{y}^{-1}$ of precipitation had, on average, 19 and $45 \%$ higher LAI in the years 2003 and 2004, respectively, than the stands with more than $910 \mathrm{~mm} \mathrm{y}^{-1}$.

\section{Leaf Morphology, Leaf Area, and Foliar $\delta^{13} \mathrm{C}$ of Leaves as Affected by a Dry and a Wet Summer}

The dry summer 2003 and the wet summer 2004 contrasted in terms of water supply during the growing season. In agreement with the leaf size
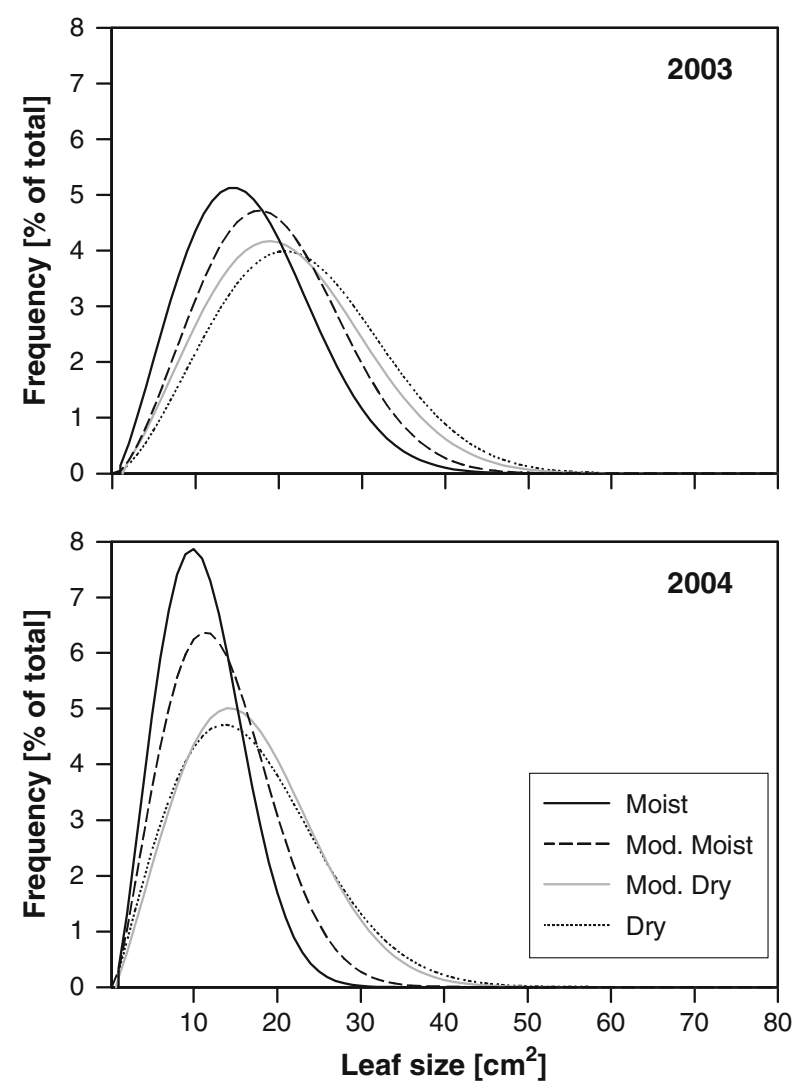

Figure 4. Size distribution in leaf populations $(n=500$ leaves per site) collected by random immediately after leaf fall in 2003 and 2004 in litter buckets (width of leaf size classes: $1 \mathrm{~cm}^{2}$ ). Mean distribution curves for moist (annual precipitation $>900 \mathrm{~mm} \mathrm{y}^{-1}$ ), moderately moist (900-750 mm), moderately dry (750-600 mm), and dry stands $(<600 \mathrm{~mm})$ are shown. Weibull functions were used to fit the curves.

trend along the precipitation gradient, mean leaf size was significantly larger in all the 14 stands under the lower-than-average summer rainfall of 2003 than in 2004 with a $20 \%$-plus rainfall in the study region (Figure 2A), just as LAI was higher in the dry summer 2003 (mean of the 14 stands: 7.2) than in wet $2004(6.8)$, in particular in the eastern low-precipitation section of the transect. The larger LAI was mainly a consequence of a higher SLA in 2003 compared to 2004, whereas leaf mass was not significantly different between the two hydrologically contrasting years. In fact, stand leaf mass averaged at $340 \mathrm{~g} \mathrm{~m}^{-2}$ in both years, irrespective of precipitation amount.

The $\delta^{13} \mathrm{C}$-signature of sun-canopy leaves increased in both the years along the transect from the high- to the low-precipitation stands (Figure $3 \mathrm{~B}$ ). The ${ }^{13} \mathrm{C} /{ }^{12} \mathrm{C}$ ratio ranged between -29.6 and $-28.1 \%$ in 2005, and between -29.4 and $-26.7 \%$ in 2006 . Beech trees growing with less 

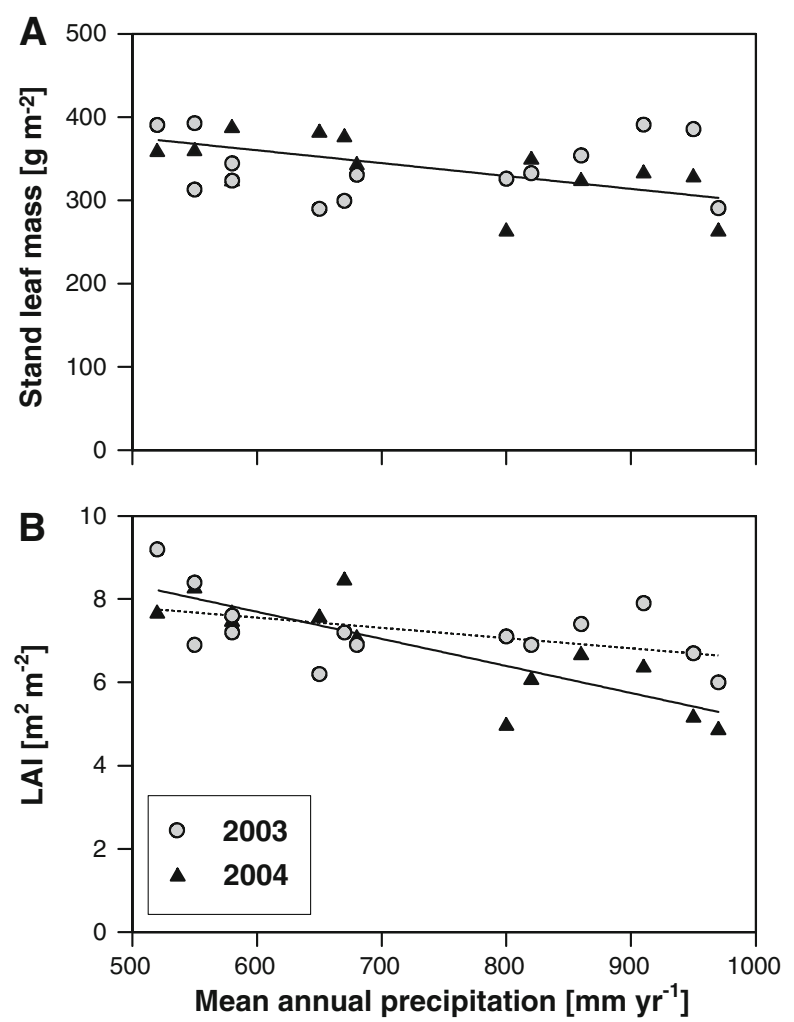

Figure 5. (A, B) Relationship between mean annual precipitation and stand leaf mass or leaf area index (LAI) in 2003 and 2004 in the 14 beech stands (LAI based on SLA values of 50 randomly selected leaves per bucket multiplied by total leaf dry mass in the buckets; $n=10$ buckets per site; leaf mass 2003: $r^{2}<0.001, P=0.48$; 2004: $y=453-0.2 x, \quad r^{2}=0.39, \quad P=0.01$; LAI 2003: $y=9.0-0.003 x, \quad r^{2}=0.22, \quad P=0.04 ; \quad 2004$ : $\left.y=11.6-0.01 x, r^{2}=0.71, P<0.001\right)$.

than $550 \mathrm{~mm} \mathrm{y}^{-1}$ of precipitation had, on average, 1.0 and $1.3 \%$ less negative $\delta^{13} \mathrm{C}$-signature of their leaves in the years 2005 and 2006, respectively, than those growing with more than $850 \mathrm{~mm} \mathrm{y}^{-1}$.

\section{Leaf Area and Leaf Morphology as Influenced by Environment and Stand Structure}

In the transect of 14 stands, precipitation was not the only variable that could have influenced leaf area and leaf morphology of beech. According to a principal component analysis, four additional ancillary gradients (mean annual temperature, stand age, stem density, and topsoil $C / N$ ratio) existed (Figure 6). On the first PCA axis, precipitation and stand age opposed to temperature. Accordingly, precipitation and stand age decreased as temperature increased. Precipitation, tempera-

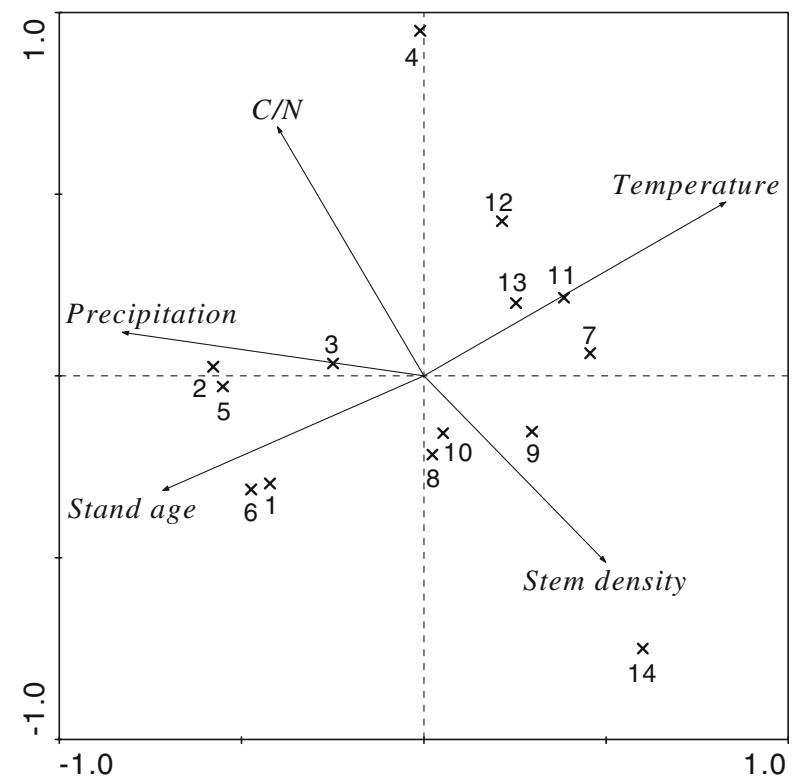

Figure 6. Principal components analysis of important environmental and stand structural parameters (mean annual precipitation, mean annual temperature, stand age, stem density, and $C / N$ ratio in the mineral topsoil ( 0 $10 \mathrm{~cm}$ )) in the 14 mature beech stands (eigenvalue of the first axis 0.462 , loading of precipitation -0.810 and of temperature 0.805; eigenvalue of the second axis 0.213 , loading of $C / N$ ratio 0.657$)$. Numbers indicate the 14 beech stands.

ture, and stand age explained together nearly 50\% of the environmental and structural variability among the stands. Stem density and soil $C / N$ on the second axis explained another $21 \%$ of the variance.

A multiple regression analysis revealed for the dry summer 2003 that leaf size was influenced most strongly by air temperature in May, but also by stem density, soil moisture, stand age (all positively), and soil $C / N$ (negatively; Table 3 ). In singlefactor correlation analyses, the influence of stem density or stand age was lacking (Table 4). In wet 2004, leaf size was exclusively a function of temperature in May, whereas the other factors had no significant effect (Table 3). The total number of leaves per ground area in 2003 was positively influenced only by summer precipitation (MaySeptember of the preceding year 2002), whereas neither air temperature, soil $C / N$, stem density, nor stand age had a significant effect (model: $r^{2}=0.31$, $P=0.04$; predictor: $F=7.5, P=0.02$ ). In 2004, none of the tested parameters had a significant effect on leaf numbers according to multiple regression analyses. However, in one-factorial correlation analyses, leaf number in 2004 was negatively influenced by base saturation (Table 4). 
Table 3. Multiple Regression Analysis on Environment Effects on Average Leaf Size

\begin{tabular}{|c|c|c|c|c|c|c|}
\hline \multirow[t]{2}{*}{$Y$} & & \multicolumn{2}{|c|}{ Model } & \multirow[t]{2}{*}{ Predictor } & \multirow[t]{2}{*}{$F$} & \multirow[t]{2}{*}{$P$} \\
\hline & & $r^{2}$ & $P$ & & & \\
\hline \multirow[t]{5}{*}{ Leaf size } & 2003 & 0.77 & 0.02 & $+\mathrm{T}$ & 10.3 & 0.01 \\
\hline & & & & $+\mathrm{D}$ & 10.1 & 0.01 \\
\hline & & & & $+\mathrm{M}$ & 10.0 & 0.01 \\
\hline & & & & $+\mathrm{A}$ & 9.1 & 0.01 \\
\hline & & & & $-\mathrm{N}$ & 6.0 & 0.04 \\
\hline Leaf size & 2004 & 0.34 & 0.04 & $+\mathrm{T}$ & 5.6 & 0.04 \\
\hline
\end{tabular}

Multiple regression analysis with backward variable elimination on the effects of soil moisture in May 2003 and 2004 (M), air temperature in May 2003 and 2004 (T), C/N ratio in the mineral topsoil $(N)$, stem density $(D)$, or stand age $(A)$ on average leaf size in the 14 beech stands in 2003 and 2004 . Values given are the determination coefficient $r$ and the probability of error $P$ for the model and the F-value and probability of error $P$ for the selected predictors. The + or - signs at the predictor variables indicate positive or negative relationships. For units refer to Tables 1 and 2.

Table 4. Correlation Analyses Between Leaf Size or Number of Leaves and Climate, Soil or Stand Structural Parameters

\begin{tabular}{|c|c|c|c|c|c|c|c|c|}
\hline & \multicolumn{4}{|c|}{ Leaf size } & \multicolumn{4}{|c|}{ Number of leaves } \\
\hline & \multicolumn{2}{|l|}{2003} & \multicolumn{2}{|l|}{2004} & \multicolumn{2}{|l|}{2003} & \multicolumn{2}{|l|}{2004} \\
\hline & $r$ & $P$ & $r$ & $P$ & $r$ & $P$ & $r$ & $P$ \\
\hline Prec 1 & -0.92 & $<0.001$ & -0.77 & 0.001 & 0.55 & 0.02 & 0.08 & 0.40 \\
\hline Prec 2 & -0.94 & $<0.001$ & -0.84 & $<0.001$ & 0.62 & 0.01 & 0.05 & 0.43 \\
\hline Prec 3 & -0.84 & $<0.001$ & -0.67 & 0.01 & 0.45 & 0.05 & -0.06 & 0.42 \\
\hline Prec 4 & -0.44 & 0.06 & -0.73 & 0.003 & 0.03 & 0.45 & -0.06 & 0.42 \\
\hline Prec 5 & -0.41 & 0.07 & -0.26 & 0.20 & 0.23 & 0.22 & -0.04 & 0.44 \\
\hline Prec 6 & -0.85 & $<0.001$ & -0.64 & 0.01 & 0.47 & 0.04 & 0.05 & 0.44 \\
\hline Prec 7 & -0.87 & $<0.001$ & -0.38 & 0.10 & 0.56 & 0.02 & -0.13 & 0.33 \\
\hline Prec 8 & -0.48 & 0.04 & -0.29 & 0.17 & 0.37 & 0.09 & -0.31 & 0.15 \\
\hline Moist 5 & 0.24 & 0.21 & 0.41 & 0.08 & -0.41 & 0.07 & -0.08 & 0.40 \\
\hline Temp 1 & 0.67 & 0.004 & 0.72 & 0.003 & -0.33 & 0.13 & 0.12 & 0.35 \\
\hline Temp 2 & 0.66 & 0.005 & 0.71 & 0.004 & -0.34 & 0.12 & 0.10 & 0.37 \\
\hline Temp 3 & 0.66 & 0.005 & 0.69 & 0.004 & -0.32 & 0.13 & 0.12 & 0.35 \\
\hline Temp 4 & 0.66 & 0.005 & 0.71 & 0.003 & -0.32 & 0.13 & 0.11 & 0.36 \\
\hline Temp 5 & 0.67 & 0.005 & 0.71 & 0.003 & -0.30 & 0.15 & 0.11 & 0.36 \\
\hline Temp 6 & 0.64 & 0.006 & 0.71 & 0.003 & -0.29 & 0.15 & 0.13 & 0.33 \\
\hline Temp 7 & 0.67 & 0.004 & 0.71 & 0.003 & -0.31 & 0.14 & 0.11 & 0.36 \\
\hline Temp 8 & 0.67 & 0.004 & 0.70 & 0.004 & -0.30 & 0.15 & 0.12 & 0.34 \\
\hline $\mathrm{N}$ & -0.42 & 0.07 & -0.42 & 0.08 & 0.20 & 0.25 & 0.07 & 0.41 \\
\hline$C / N$ & -0.24 & 0.20 & -0.09 & 0.39 & 0.24 & 0.21 & -0.05 & 0.44 \\
\hline $\mathrm{P}_{\mathrm{a}}$ & 0.16 & 0.30 & -0.19 & 0.27 & -0.15 & 0.31 & -0.34 & 0.13 \\
\hline $\mathrm{C} / \mathrm{P}_{\mathrm{a}}$ & -0.14 & 0.32 & 0.22 & 0.24 & 0.13 & 0.33 & 0.29 & 0.17 \\
\hline $\mathrm{N} / \mathrm{P}_{\mathrm{a}}$ & -0.11 & 0.35 & 0.20 & 0.25 & 0.08 & 0.39 & 0.37 & 0.11 \\
\hline Base saturation & 0.38 & 0.09 & -0.33 & 0.12 & 0.44 & 0.07 & -0.59 & 0.02 \\
\hline Stem density & 0.35 & 0.11 & 0.33 & 0.14 & 0.04 & 0.45 & 0.14 & 0.32 \\
\hline Stand age & -0.25 & 0.19 & -0.39 & 0.09 & 0.21 & 0.24 & -0.16 & 0.30 \\
\hline \multicolumn{9}{|c|}{$\begin{array}{l}\text { Results of correlation analyses between leaf size or number of leaves and each eight different measures of precipitation (Prec) and temperature (Temp) for the } 14 \text { mature beech } \\
\text { forests during the dry year } 2003 \text { and the wet year 2004, as well as soil moisture in May (Moist), total N and plant-available P in the mineral soil, stem density, and stand age. } \\
\text { Values given are the Pearson correlation coefficients } r \text { and the probability of error P. Tested were the long-term mean (1), the long-term mean from May to September (2), the } \\
\text { annual mean or sum of the study year (3), of the period from May to September of the study year (4), of April/May of the study year (5), of the respective preceding year (2002 } \\
\text { or 2003) (6), from May to September of the preceding year (7), and in August of the preceding year (8). } \\
\text { All significant correlations }(P \leq 0.05) \text { are in bold. }\end{array}$} \\
\hline
\end{tabular}




\section{Discussion}

\section{The Leaf Area-Water Supply Relationship in Forests}

Two different approaches have been used in tree physiology to analyze the relationship between water availability and leaf area in woody plants: (i) experimental studies in the laboratory or in gardens with potted seedlings or saplings, and (ii) comparative field studies along natural rainfall gradients. Precipitation has often been used as a proxy of soil water availability, because continuous soil moisture data are mostly lacking as in the present study. In this study, a close correlation between rainfall amount and soil moisture existed, in particular in the mid- to late-summer period, which justifies this approach (Figure 1B). A reduction of leaf area in drought-exposed plants can occur as a short-term response to unusual stress events or in the course of a long-term adjustment to growth-limiting water regimes. Both processes are physiologically different. In the first case, part or all of the leaves are abscised during the growing season prior to normal leaf senescence (Torrecillas and others 1999; Munné-Bosch and Alegre 2004; Bréda and others 2006); in the second case, the number of new leaf buds or the rate of leaf expansion, or both, are reduced (Fotelli and others 2000; Otieno and others 2005). The relationship between water availability (alternatively precipitation) and leaf area development may be different in the two cases.

Growth experiments with tree seedlings or saplings under contrasting soil moisture treatments may typically comprise both short-term responses to drought stress and long-term acclimation processes, because the plants most often are only partly adapted to the specific drought regime of the experiment. In contrast, field studies comparing different forest stands in contrasting environments most often reflect primarily long-term (phenotypic and genetic) adjustments to the existing water regime, whereas short-term responses to extreme drought stress events are of secondary importance. Not surprisingly, the two approaches may yield different results on the leaf area-water supply relationship.

Drought experiments with potted tree seedlings or saplings in most cases showed a reduction in average leaf size, SLA, and total leaf area per plant with increasing water shortage; this response is to be expected from basic physiological knowledge (Kozlowski and Pallardy 1997; Otieno and others 2005). However, in a few cases, contrary results were also obtained in experiments with tree seedlings (for example, Aspelmeier and Leuschner
2006). The large majority of studies in mature stands reported a positive relationship between precipitation or soil water availability and LAI, when moisture transects included a turnover of tree species or forest communities (for example, Grier and Running 1977; Kozlowski and Pallardy 1997; Bussotti and others 2000; Eamus 2003; Prior and others 2005). In studies with only one tree species, a reduction in LAI with decreasing rainfall was found in certain temperate coniferous stands (Gower and others 1992; Mencuccini and Grace 1994; Hebert and Jack 1998; Maherali and DeLucia 2001) and in species-poor tropical forests in Hawaii (Harrington and others 1995; Austin and Vitousek 1998; Ares and Fownes 1999). However, we are only aware of one study (Bussotti and others 2000) along a rainfall gradient focusing on the LAI of a temperate broad-leaved tree species.

In the present study, both average leaf size and LAI increased with a decrease in precipitation, independently of the method applied for leaf area determination (litter sampling or mid-summer leaf harvesting). This result contradicts our working hypothesis and also contrasts with the abovementioned literature data from temperate coniferous and tropical island forests with a positive precipitation-water supply relationship.

\section{Environmental Controls of Forest Leaf Area}

The unexpected increase in LAI toward the drier end of our precipitation gradient was the consequence of a significant increase in average leaf size, which more than compensated for a reduced total number of leaves in the drier stands. According to the frequency distribution diagrams in Figure 4, the number of large leaves increased in dry years and toward drier stands. To analyze the factors that may control leaf size and total leaf numbers, we applied single-factor and multiple correlation analyses. Surprisingly, not only mean annual precipitation was negatively correlated with leaf size and LAI (compare Figures 2A, 3A, and 5), but also other components of precipitation such as the longterm mean precipitation in the period May-September or in April/May of the study year, and even the precipitation of the preceding year (Table 4). This unexpected result demands a closer look at other factors such as temperature and soil nitrogen, which tend to increase with decreasing precipitation and might have direct and/or indirect effects on leaf size and LAI. In fact, mean annual precipitation was negatively correlated with mean air temperature in our sample $\left(r^{2}=0.41, P=0.01\right)$ 
and tended to increase with $C / N$ ratio $\left(r^{2}=0.12\right.$, $P=0.12$ ).

The process of leaf expansion is partly controlled by genetic constitution (adaptation), partly by the environmental conditions during leaf flushing, that is, by phenotypic plasticity (Parkhurst and Loucks 1972; Van Volkenburgh 1999; Hovenden and Vander Schoor 2004; Aspelmeier and Leuschner 2006). Besides water availability, nitrogen supply, radiation and temperature are environmental factors that are known to influence leaf expansion (Milthorpe and Newton 1963; Radin and Boyer 1982; Tardieu and others 1999; Harrington and others 2001). The radiation regime during leaf flushing is crucial for developing the sun leaf/shade leaf dichotomy within the crown (Kim and others 2005). The frequency distribution graphs of leaf size show that stands in a drier climate or in a drier summer produced more extreme shade leaves with very large size (Figure 4), whereas the total number of leaves per ground area and the number of small sun-canopy leaves decreased from the moist to the dry stands, at least in the dry summer of 2003. This indicates a more open sun canopy in drier climates or drier summers that transmits more radiation to the lower leaf strata (Sack and others 2006). In other words, in moist climates or moist summers, leaf size in the beech shade canopy seems to be more strongly limited by low light, because the sun canopy is more closed under those conditions. Any factor that reduces the density of the sun canopy would then promote leaf expansion in the shade canopy, leading to particularly large shade leaves.

Our data indicate that other factors than a higher radiation transmission through the sun canopy must also play a role in explaining the leaf size increase toward the dry end of the transect. Leaf sampling in July/August in the upper sun canopy of the stands revealed a similar increase in average leaf size toward drier sites (Figure 3A) as did the litter fall data, which represented the whole leaf population of the trees. Thus, not only the shade leaves, but also the sun leaves, increased in mean size. In the multiple regression analyses, we therefore focused on the influence of those environmental variables that could influence leaf flushing in May, that is, air temperature in May, soil moisture in May, and soil $C / N$ ratio, as well as stem density and stand age. Obviously, in both years, the largest influence on leaf area was exerted by air temperature, followed by soil moisture and stem density in 2003. In 2004, air temperature in May was the single influential factor. This indicates that leaf expansion was stimulated by higher spring temperatures.
Because cell expansion has been found to be highly sensitive to plant water deficits (Bradford and Hsiao 1982; Lu and Neumann 1998; Bray 2004), we assumed that soil water status during April and May is the most influential abiotic factor controlling leaf size of beech. However, our soil moisture measurements on all study plots in May 2004 showed ample soil water reserves (16$24 \mathrm{vol} . \%)$ in this period in all stands, indicating that drought stress cannot be a major factor in this critical period of leaf development (compare Dittmar and Elling 2006), neither in the moist nor in the dry sections of the transect.

The absence of an effect of water availability in May on leaf expansion would explain why beech leaves are equally large, or even larger, in stands with low summer rainfall as in the eastern section of the transect. In fact, a negative gradient in soil moisture from the western to the eastern end of the transect does not develop before July (Figure 1A and Schipka and others 2005). Leaf size development and summer droughts, as they develop later in the year, seem to be seasonally decoupled in temperate tree species such as beech (compare Hanson and Weltzin 2000; Wullschleger and Hanson 2006). Nevertheless, late-summer droughts can have a dramatic effect on tree physiological processes other than leaf expansion (Gebre and others 1998; Tschaplinski and others 1998; Wullschleger and others 1998; Wullschleger and Hanson 2006).

Our hydrological observations match well with the results of the regression analyses. They imply that a higher temperature in spring seems to be a significant factor promoting a larger leaf size and LAI in beech, whereas the influence of water supply is relatively small (Tables 3 and 4). The observation of Nihlgård and Lindgren (1977), who found a particularly low LAI $\left(2.9-4.3 \mathrm{~m}^{2} \mathrm{~m}^{-2}\right)$ at the northern limit of beech distribution in southern Sweden, may be viewed as support of this conclusion. Along altitudinal gradients in mountains that comprise an increase of water availability and a decrease of temperature, leaf area seems to be largely under the control of temperature (Körner and others 1986).

A better N-supply could also be one of the causes of larger leaves and a higher LAI in the stands of the drier end of our transect (Tables 3 and 4), as indicated by a weakly significant correlation with the total nitrogen pool. Soil chemical analyses evidenced not only a decrease of the $C / N$ ratio by $3 \mathrm{~mol} \mathrm{~mol}^{-1}$ with decreasing rainfall, but also indicated a tendency toward a higher base saturation in the mineral topsoil (difference not significant; Meier and Leuschner unpublished). Because all stands grow on the same geological substrate, this gradient in soil 
chemistry is thought to be caused by an increasing summer deficit in the climatic water balance toward the drier end of the transect, which reduces the leaching loss of nitrate and base cations (Yavitt and Wright 1996). Even though $\mathrm{N}$-mineralization data are missing, a better $\mathrm{N}$-supply in spring during leaf flush at the drier and more base-rich sites is likely from the well-documented close correlation between $\mathrm{C} / \mathrm{N}$ ratio, base saturation and $\mathrm{N}$-mineralization rate, and soil fertility or base saturation in temperate forest soils (Kriebitzsch 1978; Singh and Singh 1994; Van der Krift and Berendse 2001). Elevated nitrogen supply and uptake by the roots increase the synthesis of cytokinins which enhance leaf expansion (Van der Werf and Nagel 1996), implying a direct positive effect of soil $\mathrm{N}$-availability on beech leaf area. Thus, relatively mild drought stress, as it develops at $520-650 \mathrm{~mm} \mathrm{y}^{-1}$ of precipitation in the dry end of our transect, should increase $\mathrm{N}$-supply and enhance leaf expansion, thereby compensating for any negative effect of water shortage on beech leaf development.

The number of leaves produced by a beech tree is determined by the number of buds, which were formed during July or August of the preceding summer (Eschrich and others 1989). Fagus sylvatica expands its leaves in a single leaf flush in May; dormant buds for additional leaf flushes later in summer are lacking in this species. Thus, we expect that the number of leaves is primarily determined by the environmental conditions in the previous year's mid-summer period (July/August), when drought periods are usually most severe in the study region. Reductions in the tree's vitality and growth potential in mid-summer could negatively affect the number of buds produced, which should reduce the number of leaves present in the subsequent year. This produces a hang-over effect of drought stress on beech leaf area, which lasts for at least 1 year. Our multiple regression analysis with backward variable elimination revealed that the amount of precipitation in the preceding growing season (May-September) was indeed a highly influential variable determining total leaf numbers. However, this variable had a significant effect in 2003 only, but not in 2004. Other abiotic and biotic parameters that were tested such as summer temperature, soil $C / N$ ratio, or stand age had no significant influence on total leaf numbers at all.

\section{Leaf Area Development and the Drought Sensitivity of Beech}

With mean values of $6.8-7.2 \mathrm{~m}^{2} \mathrm{~m}^{-2}$, central German beech forests are maintaining a relatively high LAI compared to other broad-leaved tree species (Jaro 1959; Leuschner and others 2006b). Moreover, LAI is not reduced in close proximity to the drought limit of beech existence at the drier end of the studied transect. What is the adaptive significance of a large leaf area and relatively mesomorphic leaves in this species? Results obtained from the present study and from other investigations on the water status of mature beech trees allow some conclusions on the whole-tree drought response of Fagus sylvatica and the role played by leaf area in this context. Not surprisingly, there is multiple evidence that water shortage during mid-summer hits the leaves of the lowprecipitation stands harder than those in the moister section of the transect. First, the $\delta^{13} \mathrm{C}$-signature of sun leaf dry mass in July was significantly less negative in low than in high rainfall stands, indicating a greater reduction of leaf conductance, or a smaller maximum leaf conductance, at the drier sites (Figure 3B). A lowered leaf conductance coincided with a reduced photosynthetic activity of beech during severe drought periods as observed in gas exchange measurements in the dry summer 1996 in stand \#14 at the low-rainfall end of the transect (Landwehr unpublished results). Second, during dry summers, leaves are shed at a presenescent state in August or September in the drier stands of our transect and in other Central European beech forests on shallow soils (Stefancik 1997; Bréda and others 2006). We speculate that massive leaf losses are partly the consequence of the apparent decoupling of leaf area development in wet May and the severe summer droughts later in the year in July/August; the latter seem to hit a leaf area that is not well adapted to this kind of stress. Third, a poor match between leaf area and the severity of summer droughts may also be the cause of late-summer reductions in stem growth, which are characteristic for beech not only in dry, but also in relatively wet climates (Pigott and Pigott 1993; Lebaube and others 2000). Finally, on shallow soils, beech may suffer from periodic canopy dieback leading to elevated tree mortality rates during long dry spells (pers. observation).

Given these obvious physiological limitations, it is surprising that beech is maintaining a high LAI even in the driest environments that are tolerated by this species. This behavior reflects the conflicting demands of competitive and stress tolerating strategies on plant physiology and morphology. A high LAI is the basis not only of a relatively high carbon gain, but also of the species' ability to cast deep shade, which successfully suppresses competitors for light or soil resources (Ellenberg 1996). The 
large leaf area and its maintenance under variable environmental conditions play a key role in the survival strategy of this late-successional species. A determinate mode of leaf expansion early in the summer and the risk of physiological failure later in summer must be seen as unavoidable trade-offs in the strategy of beech to reach competitive superiority in a large variety of environments. For disentangling the full complexity of the environmental and biotic controls of leaf area development in beech, manipulative studies in controlled environments combined with field observations in mature stands are needed.

\section{ACKNOWLEDGMENTS}

The authors would like to thank Dr. H. Meesenburg (Nordwestdeutsche Forstliche Versuchsanstalt, Göttingen), Dr. D. Burk, and R. Fritz for the provision of data. We gratefully acknowledge financial support granted to I.C. Meier by the Deutsche Bundesstiftung Umwelt.

\section{OPEN ACCESS}

This article is distributed under the terms of the Creative Commons Attribution Noncommercial License which permits any noncommercial use, distribution, and reproduction in any medium, provided the original author(s) and source are credited.

\section{REFERENCES}

Aerts R. 1997. Climate, leaf litter chemistry and leaf litter decomposition in terrestrial ecosystems: a triangular relationship. Oikos 79:439-49.

Albers D, Migge S, Schaefer M, Scheu S. 2004. Decomposition of beech leaves (Fagus sylvatica) and spruce needles (Picea abies) in pure and mixed stands of beech and spruce. Soil Biol Biochem 36:155-64.

Ares A, Fownes JH. 1999. Water supply regulates structure, productivity, and water use efficiency of Acacia koa forests in Hawaii. Oecologia 121:458-66.

Aspelmeier S, Leuschner Ch. 2006. Genotypic variation in drought response of Silver birch (Betula pendula Roth): leaf and root morphology and carbon partitioning. Trees Struct Funct 20:42-52.

Austin AT, Vitousek PM. 1998. Nutrient dynamics on a precipitation gradient in Hawaii. Oecologia 113:519-29.

Backes K, Leuschner Ch. 2000. Leaf water relations of competitive Fagus sylvatica and Quercus petraea trees during 4 years differing in soil drought. Can J For Res 30:335-46.

Begg JE. 1980. Morphological adaptations of leaves to water stress. In: Turner NC, Kramer PJ, Eds. Adaptation of plants to water and high temperature stress. New York: Wiley. pp 33-42.

Berg B, Johansson MB, Meentemeyer V. 2000. Litter decomposition in a transect of Norway spruce forests: substrate quality and climate control. Can J For Res 30:1136-47.
Bradford KJ, Hsiao TC. 1982. Physiological responses to moderate water stress. In: Lange OL, Nobel PS, Osmond CB, Ziegler H, Eds. Encyclopedia of plant physiology 12B. Berlin: Springer-Verlag Berlin. pp 263-324.

Bray EA. 2004. Genes commonly regulated by water-deficit stress in Arabidopsis thaliana. J Exp Bot 55:2331-41.

Bréda N, Granier A. 1996. Intra- and interannual variations of transpiration, leaf area index and radial growth of a Sessile oak stand (Quercus petraea). Annales des Science Forestière 53:521-36.

Bréda N, Huc R, Granier A, Dreyer E. 2006. Temperate forest trees and stands under severe drought: a review of ecophysiological responses, adaptation processes and long-term consequences. Ann For Sci 63:625-44.

Burk D. 2006. Physiologische, anatomische und chemische Aspekte der Regulation der Wurzelwasseraufnahme bei Rotbuche, Kiefer und Birke auf zwei unterschiedlich wasserversorgten Standorten. PhD thesis, University of Göttingen. http://webdoc.sub.gwdg.de/diss/2006/burk/burk.pdf.

Bussotti F, Borghini F, Celesti C, Leonzio C, Bruschi P. 2000. Leaf morphology and macronutrients in broadleaved trees in central Italy. Trees Struct Funct 14:361-8.

Comps B, Thiebaut B, Paule L, Merzeau D, Letouzey J. 1990. Allozymic variability in beechwoods (Fagus sylvatica L.) over Central Europe-spatial differentiation among and within populations. Heredity 65:407-17.

Cunningham SA, Summerhayes B, Westoby M. 1999. Evolutionary divergences in leaf structure and chemistry, comparing rainfall and soil nutrient gradients. Ecol Monogr 69: 569-88.

Dittmar Ch, Elling W. 2006. Phenological phases of common beech (Fagus sylvatica L.) and their dependence on region and altitude in southern Germany. Eur J For Res 125:181-8.

Eamus D. 2003. How does ecosystem water balance affect net primary productivity of woody ecosystems? Funct Plant Biol 30:187-205.

Ellenberg H. 1996. Vegetation Mitteleuropas mit den Alpen: in ökologischer, dynamischer und historischer Sicht. Stuttgart: Ulmer UTB. 1095 pp.

Eschrich W, Burchardt R, Essiamah S. 1989. The induction of sun and shade leaves of the European beech (Fagus sylvatica L.): anatomical studies. Trees Struct Funct 3:1-10.

Fischer RA, Turner NC. 1978. Plant productivity in the arid and semiarid zones. Annu Rev Plant Physiol 29:277-317.

Fotelli MN, Radoglou KM, Constantinidou HIA. 2000. Water stress responses of seedlings of four Mediterranean oak species. Tree Physiol 20:1065-75.

Gebre GM, Tschaplinski TJ, Shirshac TL. 1998. Response in water relations of several hardwood species to throughfall manipulations in an upland oak forest during a wet year. Tree Physiol 18:299-305.

Gholz HL, Ewel KC, Teskey RO. 1990. Water and forest productivity. For Ecol Manage 30:1-18.

Gower ST, Vogt KA, Grier CC. 1992. Carbon dynamics of Rocky Mountain Douglas-fir: influence of water and nutrient availability. Ecol Monogr 62:43-65.

Granier A, Reichstein M, Bréda N, Janssens IA, Falge E, Ciais P, Grünwald T, Aubinet $\mathrm{M}$, Berbigier $\mathrm{P}$, Bernhofer C, Buchmann N, Facini O, Grassi G, Heinesch B, Ilvesniemi H, Keronen $\mathrm{P}$, Knohl A, Köstner B, Lagergren F, Lindroth A, Longdoz B, Loustau D, Mateus J, Montagnani L, Nys C, Moors E, Papale D, Peiffer M, Pilegaard K, Pita G, Pumpanen J, Rambal S, 
Rebmann C, Rodrigues A, Seufert G, Tenhunen J, Vesala I, Wang Q. 2007. Evidence for soil water control on carbon and water dynamics in European forests during the extremely dry year: 2003. Agric For Meteorol 143:123-45.

Grier CC, Running SW. 1977. Leaf area of mature north-western coniferous forests: relation to site water balance. Ecology 58:893-9.

Hanson PJ, Weltzin JF. 2000. Drought disturbance from climate change: response of United States forests. Sci Total Environ 262:205-20.

Harrington RA, Fownes JH, Meinzer FC, Scowcroft PG. 1995. Forest growth along a rainfall gradient in Hawaii: Acacia koa stand structure, productivity, foliar nutrients, and water- and nutrient-use efficiencies. Oecologia 102:277-84.

Harrington RA, Fownes JH, Vitousek PM. 2001. Production and resource use efficiencies in $\mathrm{N}$ - and P-limited tropical forests: a comparison of responses to long-term fertilization. Ecosystems 4:646-57.

Hebert MT, Jack SB. 1998. Leaf area index and site water balance of Loblolly pine (Pinus taeda L.) across a precipitation gradient in East Texas. For Ecol Manage 105:273-82.

Heim A, Frey B. 2004. Early stage litter decomposition rates for Swiss forests. Biogeochemistry 70:299-313.

Hinckley TM, Teske RO, Duhme F, Richter H. 1981. Temperate hardwood forests. In: Kozlowski TT, Ed. Water deficits and plant growth VI. New York: Academic Press. pp 153-206.

Hovenden MJ, Van der Schoor JK. 2004. Nature vs. nurture in the leaf morphology of Southern beech, Nothofagus cunninghamii (Nothofagaceae). New Phytol 161:585-94.

IPCC 2001. Climate change 2001: the scientific basis. Contribution of working group I to the third assessment report of the Intergovernmental Panel on Climate Change. Cambridge: University Press. 881 pp.

IPCC 2007. Summary for policymakers. In: Solomon S, Qin D, Manning M, Chen Z, Marquis M, Averyt KB, Tignor M, Miller HL, Eds. Climate change 2007: the physical science basis. Contribution of working group I to the fourth assessment report of the intergovernmental panel on climate change. Cambridge, New York: University Press.

Jaro Z. 1959. The leaf area in some forest types. Erdsz Kut 6:10310.

Jose S, Gillespie R. 1997. Leaf area-productivity relationships among mixed-species hardwood forest communities of the central hardwood region. For Sci 43:56-64.

Kim GT, Yano S, Kozuka T, Tsukaya H. 2005. Photomorphogenesis of leaves: shade-avoidance and differentiation of sun and shade leaves. Photochem Photobiol Sci 4:770-4.

Körner C, Bannister P, Mark AF. 1986. Altitudinal variation in stomatal conductance, nitrogen content and leaf anatomy in different plant life forms in New Zealand. Oecologia 69:577-88.

Kozlowski TT, Pallardy SG. 1997. Physiology of woody plants. San Diego: Academic Press. 411 pp.

Kriebitzsch W-U. 1978. Stickstoffnachlieferung in sauren Waldböden Nordwestdeutschlands. Scripta Geobotanica (Göttingen) 14:1-66.

Lebaube S, Le Goff N, Ottorini J-M, Granier A. 2000. Carbon balance and tree growth in a Fagus sylvatica stand. Ann For Sci 57:49-61.

Leuschner Ch, Meier IC, Hertel D. 2006. On the niche breadth of Fagus sylvatica: soil nutrient status in 50 Central European beech stands on a broad range of bedrock types. Ann For Sci 63:355-68.
Leuschner Ch, Voss S, Foetzki A, Clases Y. 2006. Variation in leaf area index and stand leaf mass of European beech across gradients of soil acidity and precipitation. Plant Ecol 186:247-58.

Lof M, Welander NT. 2000. Carry-over effects on growth and transpiration in Fagus sylvatica seedlings after drought at various stages of development. Can J For Res 30:468-75.

Lu ZJ, Neumann PM. 1998. Water-stressed maize, barley and rice seedlings show species diversity in mechanisms of leaf growth inhibition. J Exp Bot 49:1945-52.

Maherali H, DeLucia E. 2001. Influence of climate-driven shifts in biomass allocation on water transport and storage in Ponderosa pine. Oecologia 129:481-91.

Mencuccini M, Grace J. 1994. Climate influences the leaf area/ sapwood area ratio in Scots pine. Tree Physiol 15:1-10.

Milthorpe FL, Newton P. 1963. Studies on expansion of leaf surface. 3. Influence of radiation on cell division and leaf expansion. J Exp Bot 14:483-95.

Munné-Bosch S, Alegre L. 2004. Die and let live: leaf senescence contributes to plant survival under drought stress. Funct Plant Biol 31:203-16.

Nihlgård B, Lindgren L. 1977. Plant biomass, primary production and bioelements of three mature beech forests in South Sweden. Oikos 28:95-104.

Otieno DO, Schmidt MWT, Adiku S, Tenhunen J. 2005. Physiological and morphological responses to water stress in two Acacia species from contrasting habitats. Tree Physiol 25:361-71.

Parkhurst DF, Loucks OL. 1972. Optimal leaf size in relation to environment. J Ecol 60:505-37.

Pedrol N, Ramos P, Reigosa MJ. 2000. Phenotypic plasticity and acclimation to water deficits in velvet-grass: a long-term greenhouse experiment. Changes in leaf morphology, photosynthesis and stress-induced metabolites. J Plant Physiol 157:383-93.

Peuke AD, Schraml C, Hartung W, Rennenberg H. 2002. Identification of drought-sensitive beech ecotypes by physiological parameters. New Phytol 154:373-87.

Pigott CD, Pigott S. 1993. Water as determinant of the distribution of trees at the boundary of the Mediterranean zone. J Ecol 91:557-66

Poorter H. 1989. Interspecific variation in relative growth rate: on ecological causes and physiological consequences. In: Lambers H, Cambridge ML, Konings H, Pons TL, Eds. Causes and consequences of variation in growth rate and productivity of higher plants. The Hague: SPB Academic Publishing. pp. 45-68.

Prior LD, Bowman DMJS, Eamus D. 2005. Intra-specific variation in leaf attributes of four savanna tree species across a rainfall gradient in tropical Australia. Aust J Bot 53:323-35.

Radin JW, Boyer JS. 1982. Control of leaf expansion by nitrogen nutrition in sunflower plants-role of hydraulic conductivity and turgor. Plant Physiol 69:771-5.

Reich PB, Ellsworth DS, Walters MB, Vose JM, Gresham C, Volin JC, Bowman WD. 1999. Generality of leaf trait relationships: a test across six biomes. Ecology 80:1955-69.

Rowell DP, Jones RG. 2006. Causes and uncertainty of future summer drying over Europe. Clim Dyn 27:281-99.

Runyon J, Waring RH, Goward SN, Welles JM. 1994. Environmental limits on net primary production and light-use efficiency across the Oregon transect. Ecol Appl 4:226-37.

Sack L, Melcher PJ, Liu WH, Middleton E, Pardee T. 2006. How strong is intracanopy leaf plasticity in temperate deciduous trees? Am J Bot 93:829-39. 
Schipka F, Heimann J, Leuschner C. 2005. Regional variation in canopy transpiration of central European beech forests. Oecologia 143:260-70.

Singh H, Singh KP. 1994. Nitrogen and phosphorus availability and mineralization in dryland reduced tillage cultivation-effects of residue placement and chemical fertilizer. Soil Biol Biochem 26:695-702.

Stefancik I. 1997. Phenology of beech (Fagus sylvatica) in two different localities in central Slovakia. Biologia 52:33-40.

Tardieu F, Granier C, Muller B. 1999. Modelling leaf expansion in a fluctuating environment: are changes in specific leaf area a consequence of changes in expansion rate? New Phytol 143:33-44.

Torrecillas A, Galego R, Pérez-Pastor A, Ruiz-Sánchez MC. 1999. Gas exchange and water relations of young apricot plants under drought conditions. J Agric Sci 132:445-52.

Tschaplinski TJ, Gebre GM, Shirshac TL. 1998. Osmotic potential of several hardwood species as affected by manipulation of throughfall precipitation in an upland oak forest during a dry year. Tree Physiol 18:291-8.

Turner IM. 1994. A quantitative analysis of leaf form in woody plants from the world's major broadleaved forest types. J Biogeogr 21:413-9.

Van der Krift TAJ, Berendse F. 2001. The effect of plant species on soil nitrogen mineralization. J Ecol 89:555-61.
Van der Werf A, Nagel OW. 1996. Carbon allocation to shoots and roots in relation to nitrogen supply is mediated by cytokinins and sucrose: opinion. Plant Soil 185:21-32.

Van Volkenburgh E. 1999. Leaf expansion-an integrating plant behaviour. Plant Cell Environ 22:1463-73.

Welander NT, Ottosson B. 1997. Influence of photosynthetic photon flux density on growth and transpiration in seedlings of Fagus sylvatica. Tree Physiol 17:133-40.

Wright IJ, Reich PB, Westoby M, Ackerly DD, Baruch Z, Bongers F, Cavender-Bares J, Chapin T, Cornelissen JHC, Diemer M, Flexas J, Garnier E, Groom PK, Gulias J, Hikosaka K, Lamont BB, Lee T, Lee W, Lusk C, Midgley JJ, Navas ML, Niinemets U, Oleksyn J, Osada N, Poorter H, Poot P, Prior L, Pyankov VI, Roumet C, Thomas SC, Tjoelker MG, Veneklaas EJ, Villar R. 2004. The worldwide leaf economics spectrum. Nature 428:821-7.

Wullschleger SD, Hanson PJ. 2006. Sensitivity of canopy transpiration to altered precipitation in an upland oak forest: evidence from a long-term field manipulation study. Glob Chang Biol 12:97-109.

Wullschleger SD, Hanson PJ, Tschaplinski TJ. 1998. Whole-plant water flux in understory Red maple exposed to altered precipitation regimes. Tree Physiol 18:71-9.

Yavitt JB, Wright SJ. 1996. Temporal patterns of soil nutrients in a Panamanian moist forest revealed by ion-exchange resin and experimental irrigation. Plant Soil 183:117-29. 